\title{
特集に寄せて
}

\author{
マイクロメカトロニクス実装技術委員会 \\ 生産流通トレーサビリティと感性計測技術研究会 幹事 \\ 一木 正聡 ${ }^{*}$
}

\section{Intention to the Special Edition}

\author{
Masaaki ICHIKI*
}

* 東京大学大学院工学系研究科精密機械工学専攻（†113-8656 東京都文京区本郷 7-3-1）

* Department of Precision Engineering, School of Engineering, Graduate School of the University of Tokyo (7-3-1 Hongo, Bunkyo-ku, Tokyo 113-8565)

産業構造のグローバリゼーション・ボーダーレス化の進 展に伴い, 工業製品や農業製品などあらゆる生産財の製造 工程は, 国際的な分業・協業が一般的となってきた。これ に伴い, 農業製品や食品の安全性やトレーサビリティ, 工 業製品の品質保証が重要な課題となっている。夕グに代表 されるユビキタス技術は，これらの課題を解決することの できる有望技術として注目されているが，低コスト化や データ人出力の自動化, さらにはカスタム化開発が行われ ていないという問題点がある。特に，従来行われてきた人 間がデータを入力することは作業のコストという観点以外 に, 改䆝などの入力データの信頼性への䀣念が予想される。 また, 要素技術は高度化しつつあるもののカスタム化され たデバイス開発がなされていないために，技術の普及が速 やかに行われないことが現実化している。

一方, 重大事件 ·事故の内在要因の 1 つとしてヒューマ ンエラーの重要性が指摘されており, 作業者のストレスや 疲労度などの状態モニタリングを実現するための各種セン サ開発，およびその時系列解析・予測手法の開発の必要性 が注目されている。とくに，作業現場においては，作業の 中断なしに採取できる測定対象から覚醒, ストレスや疲労 などの度合いをオンサイトで定量測定できるシステムが必 要とされており, 時系列データの解析による状態判定と予 測技術をデバイスと組み合わせて開発することが求められ ている。例えば，睡眠障害に起因する危険行動などは自覚 症状がないままに発生する危険性があるため, 人間状態の 計測評価技術は今後の安心・安全社会実現のために必要不 可欠な技術としてその基盤技術の整備が必要とされている。

ところで, 近年はMEMSなどの微細なセンサ・アクチュ エータの製造技術の開発に伴い，各種のセンシング技術は 急速に技術の進展が行われている。また，ITの普及による ネットワーク技術も急速に普及しており，これらの融合技 術であるセンサネットワーク技術の進展が上記のユビキタ ス技術の中核となることが期待されている。

このような状況に鑑み，国内の産学官各分野においてご
活躍の研究者 ·技術者の皆様の協力の下に, 本小特集「生 産流通トレーサビリティと人間状態計測における現状とセ ンサネットワーク応用一安全・安心社会の実現に向けた取 り組み」を企画した。以下の各編では, 人工衛星システム について林先生に先行したユビキタス技術としての現状を ご紹介いただいた。水素センサシステムでは，松原博士ら に感性計測技術としての視点から執筆をお願いした。小故 島氏には活発な製品化を推進中のセンサ端末の技術動向に 関してご説明いただいた。岡田氏には, 状態計測用に特徵 ある製品開発の現状をお願いした。執筆者はいずれも業務 上たいへんお忙しい方ばかりであり, 本小特集の趣旨にご 賛同いただき，最新の技術開発動向をまとめていただいた ことに改めて感謝申し上げる。

ここで, 手前味噌となるが著者らが参加している研究会 の紹介を申し上げる。マイクロメカトロニクス実装技術委 員会には, 生産流通トレーサビリティと感性計測技術研究 会（委員長：佐野利男 千葉工大・教授）が 2007 年 10 月 より設置されている。この研究会では，RF-TAGやネット ワーク技術, センサ技術などの最先端の技術を取り込み, 安全でコストのかからない生産流通プロセスのトレーサビ リティならびに人間状態計測・評価技術に関する調查研究 を行うことにより，安心・安全社会実現への具体的なデバ イス提案とそのために必要な実装技術上の諸課題を抽出し, 今後の速やかな実用化への貢献を目的としている。今回の 技術内容はいずれもこの研究会の活動に参加している構成 員の紹介や研究会報告という縁により実現したものである。 今後は公開討論会の開催も企画されており，また追加して メンバの募集も行っており，ご興味のある読者諸氏の参加 をお願いしたい。

最後に本小特集が, 読者各位の本分野の最近の動向を知 る上でのよき指針をなることを期待する。また，本企画に あたって澤田廉士編集委員長 (九州大学・教授) からのお 勧めがあったことを付して感謝の意を表すこととする。 